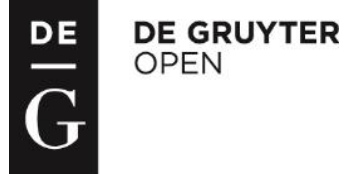

* Onoriu Colăcel

Faculty of Letters and Communication Sciences,

Ştefan cel Mare University of Suceava,

13 Universităţii Street, 720229 Suceava, Romania

e-mail: onoriucolacel@litere.usv.ro

\title{
EDIBLES AND OTHER OFFERINGS TO READERS: THE POLITICS OF GENDER AND FOOD IN NARRATIVE FICTION
}

\begin{abstract}
From the perspective of an apparently absent author, the rhetorical commonplaces of womanhood and nourishment are mentioned in the novels of Margaret Atwood, The Edible Woman (1969), and of Jillian Medoff, Hunger Point (2002). Although traditionally relegated to contextualizing devices, the unfolding of events makes a riddle out of cooking and eating for the purpose of dramatic effect. Reporting on what might come across as domestic chores points to the topicality of food intake as well as to all the drama eating disorders entail. In the background of events, the 'whodunit' and the 'kitchen sink drama' come together into one unlikely story. The benefits of hindsight make it possible to argue that celebrated feminist novels of the past century, i.e. The Edible Woman, provided later $21^{\text {st }}$ century fiction, i.e. Hunger Point, with something more than narrative emphasis on binary gender relations. I find that the gender-roles debate, as recorded in Atwood's work, gained enough cultural momentum to prove the ready availability of the image of the nurturing female throughout the $20^{\text {th }}$ century and beyond. As far as feminist fictions are concerned, over/under-feeding is always somewhere in the background, if not what drives the plot forward. Commonly, distress among fictional characters, mostly women, is linked to body weight and dieting in ways that threaten to relegate, possibly once and for good, the notions of women and food to the realm of melodrama, as it is the case with Hunger point.
\end{abstract}

Keywords: gender roles, food, eating disorders, proto/popular feminism

My reading of Margaret Atwood's possibly most famous novel, The Edible Woman (1969), aims to track down the legacy it passed on to early $21^{\text {st }}$ century fictional examination of gender narratives. As far as literary history is concerned, minor contemporary novelists fall back to the achievements of celebrated $20^{\text {th }}$ century authors in order to come to terms with the on-going challenges posed by the rhetoric of gender roles. For instance, Margaret Atwood's novel comes to mind whenever the theme of female identity, food intake and eating disorders are brought to the fore of popular $21^{\text {st }}$ century novels. I find that a rather successful first novel of Jillian Medoff, Hunger point (2002), makes the most out of a proto-feminist discourse, as originally exemplified by The Edible Woman. Creative writing suggests that self-starving female characters and the way they choose to identify (or not) with food are instrumental in popular gender self-definition. They have always been effective means to tell the story of most women eligible to become heroines. The theme of food in the novel genre is of great consequence for character delineation, considering that all the concerned parties, male and female, seem to be judging each other's eating habits.

With the benefit of hindsight, it feels safe to say that the novel has accommodated the selfaware discourse of female authors throughout the history of the genre, ever since the late 1960s. The literature under scrutiny has everything to do with the subject matter of feminism. Yet, fictional accounts of gender roles and eating disorders have lost track of what theory has to say about various strands of feminism. The above-mentioned is particularly true of one specific $21^{\text {st }}$ century popular novel about "doing weird things with food" (Medoff, 2002: 20). This and other similar concerns revolving

\footnotetext{
* Dr Onoriu Colăcel is Reader in English at Ștefan cel Mare University of Suceava, Romania. His work focuses on contemporary English literature and patterns of self-identification in media and popular culture.
} 
around food and self-identification trigger the unfolding of events. The female narrators of Atwood and Medoff strive to make readers aware of a conflict only made visible by cooking and eating.

Both novels convey the general notion that feminist theory and fictional practice are miles apart. Here is what a 2009 rather influential postfeminist book states about current reconfigurations of feminist thought: "postfeminism is both retro- and neo- in its outlook and hence irrevocably post-. It is neither a simple rebirth of feminism nor a straightforward abortion [...] but a complex resignification..." (Genz; Brabon, 2009: 8). While postfeminism struggles to make sense for the average reader, actual storytelling about female characters reflects on matters that are more mundane. To cut a long story short, the characters' everyday behaviour spirals out of control. Anxiety, depression, and suicide are in the spotlight mostly due to their love affair with food that has gone wrong. Everything happens in the hope that an eventful storyline does not fail to involve readers in often-hackneyed accounts of daily life. The last consequence of food related anxieties is always around the corner: "whenever I'm feeling overwhelmed, I remind myself that I can always kill myself and I start to feel better" (Medoff, 2002: 2007). Most of the times, female characters are fascinated with morbid loss of appetite, emotional trauma and death, which all lurk beneath the surface of ordinary lives. On the one hand, the routine of cooking and eating essentially helps readers place in context the plot curve. On the other hand, "women's centrality to food practices" (Voski Avakian; Haber, 2005: viii) is something of a statement on its own.

Very much in tune with the past of critical theory, late $20^{\text {th }}$ century feminism concluded that "there is no clear agreement as to what third wave feminism is even about" (Spencer, 2007: 298). One thing is for sure, stories about food serve to explain the development of gender identity as recorded in feminist fictions, which are very much concerned with notions of body-image. It turns out that food is "a constant and necessary presence in human life, [that helps us] to investigate the complexity of women's intersecting social identities" (Voski Avakian; Haber, 2005: vii). Finally, the attempt at selfscrutiny in the presence of food brings about all the narrative clichés of the 'whodunit' as well as of a $21^{\text {st }}$ century 'kitchen sink drama'.

My reading of the already mentioned novels deals with the rhetorical commonplaces of womanhood and nourishment, as they are told for the benefit of absent, yet plain to see, other characters. They are witnesses to the story rather than its subjects. When it comes to eating, the likely guess is that the readers (or, anyway, someone who eats differently) are called upon to tell apart "mental collapse" (Atwood, 2010: 38) from "self-conscious performance" (Atwood, 2010: 39). The others are signified either as the "male gaze" (Mulvey, 1975: 11) or, possibly, as healthy (fe)male readers. However, the company of this conspicuous Other makes it possible to argue that both novels read gender roles through the very same lens. The female narrators put on a show that is meant to entice readers away from taking eating and food for granted.

The Edible Woman provided later $21^{\text {st }}$ century fiction with something more than narrative emphasis on binary gender relations. Atwood's take on young female characters gained enough cultural momentum to prove the ready availability of the image of the nurturing female throughout the $20^{\text {th }}$ century and beyond. As far as the novel genre is concerned, food deprivation and over-feeding have always lurked in the background ever since. Generally, distress among fictional women is linked to body weight and dieting. Everything happens in ways that threaten to relegate, possibly once and for good, the notions of women and food to the realm of melodrama.

In a melodramatic manner, Jillian Medoff's Hunger point rewrites the story of growing fat and getting thin by means of the violent emotions triggered by sensational incidents. The compulsion to scrutinize food is the starting point of the eventual breakdown female characters perform dutifully as they face the challenges of daily life. However, Atwood's novel provides plenty of examples that signal the advent of food intake as the plot trigger of impending psychological meltdown, something able to define female identity by its sheer presence. For example, as early as the 1970s, fictional women engaged in exchanges that are riddled with references to the sensuous (as well as intellectual) perception of what is edible, as if food and the routine of cooking necessarily had something to do with their selfidentification. For instance, the epic of egg cooking is bound to catch the eye of the reader:

I was wandering whether I could face an egg. [...] I manoeuvred the egg into the saucepan; it cracked immediately. It was straight out of the refrigerator and too cold. I inspected my egg, which was sending out a white semi-congealed feeler like an exploring oyster. It's probably done and I 
fished it out. [...] I whacked my egg against the side of my dish and got my thumb stuck in it. It wasn't done after all. (Atwood, 2010: 55)

As seen above, reflecting on "doing weird things with food" (Medoff, 2002: 3) - a leitmotif that runs through Medoff's novel - had a start with The Edible Woman. Explicitly, the 1970s novel is informative of the way literary language is employed to phrase a sense of failure that the main characters experience on a daily basis. Each time something goes wrong, they are eager to let themselves go on a food binge, while searching for the reasons that should explain their current condition. Popular (mis)conceptions about nutrition are at play in the narrative of each and every character. In both novels, the love lives of the heroines, as well as that of their boy-friends, are associated to the imagery of eating. The bottom line is that, essentially, they feel rejected: "Why can't I meet someone who loves me? In movies, girls always have two guys to choose between. I can't even find a drunk guy to throw myself at. I hate my life. I hate every fucking thing about it. I wish I were dead" (Medoff, 2002: 77).

Both novels reveal that food-related afflictions are social, inasmuch as they surface only when eating together is in order. It follows that body-image is to a large extent self-image. The notion of eating properly is assumed to be the reason why one is rewarded or punished by society. Atwood's story has come to be known as a feminist novel, although as early as 1979, she argued against the self-aware 'feminism' of the novel: "I myself see the book as protofeminist rather than feminist" (Atwood, 1982: 370). Whether or not (proto)feminist, the novel exemplifies the detective-fiction setup of reporting on female identity as nothing less than an article of food. Most likely, the title on its own has made it into the mainstream of popular culture and greatly contributed to the critical afterlife of The Edible Woman. Much like the image of the nurturing female, most edible identities belong to characters who turn to mystery-solving. Somehow, this is a condition neither undesirable nor pleasing. Finding out who has done what is the very gist of storytelling. At any rate, it expresses an action that passes over to the object of narrative attention - i.e. to young females and their struggle to gain social recognition and, all things considered, formal employment and romantic love. Fictional invention insistently comes back to menial jobs like house chores (cooking included), which come across as increasingly important. Moreover, the choice of a partner is openly considered in terms of his personal 'neatness' and ability to advertise his own fitness. Unreservedly, the same dieting commitment women themselves fight to keep up with is at the core of all romantic involvements expected to lead to marriage: "He's attractive and he's bound to be successful and also he's neat which is a major point when you are going to be living with someone. [...] We'll probably have to live in an apartment at first, but later we can have a real house [...]; it will be worth the trouble to keep clean" (Atwood, 2010: 66).

Body weight and over/under-feeding work together to develop a set of benchmarks against which men and women judge themselves and others. Family members and roommates discuss the way each of them lives up to such expectations, not to mention the circumstances of living under the same roof. In so many words: "I also know they view me as a houseguest who is turning a weekend stay into an all-expense-paid lifelong residency, and who (to their horror) constantly forgets to flush the toilet and shut off the lights" (Medoff, 2002: 11-12). As far as Jillian Medoff's novel is concerned, eating disorders have everything to do with standards of social and moral propriety, and, nothing less than survival. Considering that her characters are constantly depicted in the process of emptying the contents of their bowels (one way or another!), the reader cannot help feeling that all women characters are survivors of a war that wages in the kitchen of many homes. Explicitly, if they made it alive out of the prison cage of Western beauty ideals by the end of the plot, it must be that they are full-fledged heroes - which is the case of Medoff's protagonist who lost her sister to anorexia. Hunger point follows in the footsteps of The Edible Woman's female narrator who gave the epic description of what happens when cooking a cold egg, fresh from the refrigerator. Of course, such actions are carried forward to their last consequence in the $21^{\text {st }}$ century novel:

I gulped milk, and the cookies expanded in my stomach, the nuts grew big as acorns. I felt everything rising so I rushed into the bathroom and lay on the floor. [...] I stuck my finger in my mouth, tentatively at first, then harder, so hard, I jabbed the back of my throat. I gagged until I spewed milky brown water and I kept gagging, heaving chunks of unchewed cookie. A few times I missed the toilet, and spots of chocolate sprayed the clean white tiles like droplets of blood. (Medoff, 2002: 7-8) 
Fictional women and food are relegated to the realm of melodrama. Every step of the way, dire consequences are predicted. Consequently, it is hard to tell apart factual reporting from "highly affective scenes of pathetic or virtuous suffering" (Butt, 2014: 30). Actually, Hunger Point was made into a TV movie in 2003, a screen adaptation whose violent appeal to feelings is a side effect of eating habits gone bad. Its happy-ending and the characters' emotional bursts are unmistakably sensationalist. The address of her narrator puts on display coarse language and vivid descriptions of bodily functions. If The Edible Woman heralded most if not all of the usual props commonly used by the mainstream narrative of feminism, Jillian Medoff's Hunger Point aggravates whatever has been already said against the rhetoric of feminism. Notions of equality are caricatured in the attempt to define characters and, by association, gender roles.

The novel genre gives a survey of the way popular culture construes feminism as political agency in the cultural past. More often than not, the language of feminism is ultimately historicized. As a result, popular female self-identification patterns, emptied of political meanings, are enlisted to help convey the message of fiction, irrespective of what used to be the political commitment of feminism to deliver social change. Both The Edible Woman and Hunger Point feature the rhetorical commonplaces of womanhood and nourishment in order to define their young female heroes. The statements documenting the overlap between gender and eating should make readers better understand the female characters and the world they live in. For instance, she trailed "herself like a many plumed-fish lure $[\ldots]$ through the likely-looking places, good restaurants and cocktail bars where the right kind of men might be expected to be lurking, ravenous as pike, though more martially inclined" (Atwood, 2010: 71). The girls had "ceremonial food hangovers and New Year's dieting resolutions" (Medoff, 2002: 5). The young woman "put some of the dark green vegetable substance into her mouth, tentatively, as one would make an offering to a possibly angry god. It was accepted" (Atwood, 2010: 121). Some women have "an obvious lack of self-control with food" (Medoff, 2002: 26).

To some extent, their female characters render ineffective the critical assessment of patriarchal society, something that the feminist authors are famous for. What used to be a language of dissent, employed to demand equal rights for women, is essentially aestheticized by writers obviously concerned with the fate of their novels, rather than with that of women in modern Western society. For the sake of proficient storytelling, the plot is built on the detective-story pattern. The Other and the feminine self are scrutinized whenever they relate to food, cooking, and over/under-feeding, rather than when they take action to right the wrongs of gender discrimination. Alongside other literary motifs and themes, a version of (proto)feminism seems to be embedded in literary invention, not for its own sake as much as for the sake of character delineation. Factually, it is part of gender self-identification as recorded in the language of Western popular culture. All the same, the rhetoric of women liberation is an asset to fiction. Conclusively, storytelling about food and food deprivation relies on the 'whodunit' cliché placed in the context of a revamped 'kitchen sink drama' aesthetics. In both novels, young corporate professionals, sometimes out of a job, living with their parents or in an apartment, spend their time eating too much or too little and being miserable about it. This invites an association between the so-called protofeminism and the popular construal of feminism.

In a compelling manner, the novel genre promotes middle of the road gender narratives. While at it, it defines feminism in terms of historical events, which deserve the attention of whoever has the time and the willingness to re-discover their long forgotten meanings. In other words, the readily available version of Atwood's proto-feminism is nowadays popular feminism. Namely, it is a story everybody knows by heart, a celebratory account of the political agency of women in modern history. The downside of it is that, in prioritizing their sense of gender identity, female fiction writers instrumentalize food to political ends that they themselves choose to ignore as they go about telling their story.

Works Cited

Atwood, M., 2010, The Edible Woman. McClelland \& Stewart Emblem. EPUB File. 1969.

Atwood, M., 1979, Second Words. Selected Critical Prose, Ananasi. PDF File. 1982.

Butt, R., 2014, "Melodrama and the Classic Television Serial", pp. 27-41, in Stewart, M., (ed),

Melodrama in Contemporary Film and Television, Palgrave Macmillan: Hampshire and New York. 
Genz, S., Brabon, B., A., 2009, Postfeminism. Cultural Texts and Theories, Edinburgh University Press.

Mulvey, L., 1975, "Visual Pleasure and Narrative Cinema" in Screen, 16 (3), pp. 6-18.

Medoff, J., 2002, Hunger Point, Harper Collins e-books. PDF File.

Gillis, S., Howie, G., Munford, R., (eds.), 2007, Third Wave Feminism. A Critical Exploration, Expanded Second Edition, Palgrave Macmillan: New York.

Voski Avakian, A., Haber, B., (eds.), 2005, From Betty Crocker to feminist food studies: critical perspectives on women and food, University of Massachusetts Press: Amherst \& Boston. 